\title{
THE TEXT-BUILDING FUNCTIONS OF WORD-FORMING ELEMENTS
}

\author{
VASYL GRESHCHUK
}

\begin{abstract}
The article discusses the role of word formation in text production. It is argued that word-forming elements can perform various functions connected with text production. Derivational elements serve as starting structural and semantic material for textual categories; they create local and global textual connections; allow for an unambiguous representation of information thus eliminating cumbersomeness and syntactic overload; enable textual progression; and contribute to generating textual connotations. Word-forming elements (both basic and complex ones) perform different text-oriented functions.
\end{abstract}

Keywords: coherence, cohesion, text production, text progression, textual connotation, word formation, word-forming elements.

\section{INTRODUCTION}

Word formation has long been a focus of important linguistic studies; and as regards word-forming resources, types and means of word formation, as well as the structural organization of the wordforming system, modern linguistics has accumulated a significant body of research to date. However, little attention has been given to the functional aspect of word formation, for instance the role of wordforming elements and categories in text production.

The paper is aimed at exploring the role of word formation in text production and illustrating it with relevant texts.

\section{ANALYSIS AND Discussion}

While studying the functions of word formation in text production, it is necessary to consider the fact that word-forming elements vary from basic to complex ones, which determines their potential for text production.

Derivational elements such as word-forming affixes and stems have no denotational function, nor can they be independent components of the text - only as parts of derivatives. When used in certain positions in micro-texts, derivatives of the same word, derivational antonyms or paronyms, etc. serve as means of textual expressivity; in other words, they create connotations, and due to being repeated, they also maintain the local connectedness of a text, cf.: Переживу. Перечорнію. / Перекигич. Пропаду. 
/ Зате - нічого. Все. Німію. / Байдужість в голови кладу“ (M. Vinhranovskyi. Ne rush mene) (I'll get over it. I'll stop being black with grief. / I'll stop squawking. I'll disappear. / But it doesn't matter. That's all. I'm getting numb. / Putting indifference into my head**) (M. Vinhranovskyi. Don't Bother Me); Зраділий, / Я обізвався серцем в світ, / I вже крізь тебе пораненько / Я крикнув, повен сил і дій: / - Мій світе, світку, світотенько, / Мій світонько, світище мій! (M. Vinhranovskyi. Stansy) (Glad, / I talked to the world with my heart, / And early in the morning, inside of you, / I shouted, full of strength and action: / My world, little world, dear tiny world, / My dear little world, my huge world!) (M. Vinhranovskyi. Stanzas).

In the micro-texts given above, the derivational elements which are repeated "serve as linking devices for expressing a single meaning, which enhances textual unity and emphasizes the prosodic organization of the verse" $[5$, p. 21].

When a derivational formant is separated and lexicalized [3], it assumes the function of specific nomination with a rather high degree of generalization or, in other words, the function of semantic inclusion of a derivational set, cf.: О давній наш максимахізм, / Святе обурення на того, / Хто убачав якийсь там "ізм" / Або прихильність до старого (O. Riznychenko. O yunyi nash maksymalizm) (Oh, our long-standing maximalism, / A holy indignation at one / Who was able to trace an "ism" of some sort / Or adherence to the old) (O. Riznychenko. Oh, Our Youthful Maximalism).

The lexicalized suffix -izM expresses the generalized meaning of any derivative containing a common structural word-forming affix.

In text linguistics, the lexical and semantic components of a text are usually disregarded because the discipline mostly focuses on units longer than a sentence. Since its emergence on, text linguistics has regarded a coherent text as a consistent set of sentences linked with each other semantically in line with the author's general idea [9, p. 6].

Depending on the aspects of text analysis and research frameworks, various text elements and levels come into focus. The traditional, systemic, framework identifies text levels in accordance with the main language domains: phonetic and phonological, morphological, lexical and semantic, and syntactic [1, p. 126]. The lexical and semantic level of a text is composed of nominative word-level units, for instance derivative words, among others.

As O.S. Kubriakova rightfully stresses, "the emergence of the word-forming system with all its devices and patterns is obviously connected with two factors. One of them is the need for new means of nomination, new lexemes, since one of the goals of word formation is enriching the vocabulary of a language. The other, no less powerful, factor contributing to the development of the word-forming system is the need for aligning the form and content of secondary units of nomination with their future syntactic roles and, no less importantly, with their functions regarding the whole text and the rational organization of the latter" [6, p. 179]. It is from this perspective that we will discuss the functions of derivatives in the process of text generation. However, first let us consider the following points.

The constitutive function, that is one connected with creating higher-order language units, must be attributed not only to the phoneme, but also to derivative words as units which build sentences and consistent sets of sentences linked with each other semantically.

The word formation development factors identified by O.S. Kubriakova are based on the differentiation between lexical and syntactic derivation [7]. As regards text production, we do not treat lexical and syntactic derivatives as two separate types despite the fact that they possess certain differences. Both lexical derivatives and syntactic derivatives as derivative words, units of word formation resulting from derivational reduction aimed at condensing an utterance without essential loss of information, accumulate the meaning of the semantic and syntactic structure of their motivating sentences or word combinations [2, p. 133]. Due to this function in text generation, derivatives allow for an economical and unambiguous representation of information, which helps to avoid grammatical overload and syntactic complication. Considering the fact that in multi-genre texts derivative words

\footnotetext{
${ }_{* *}^{*}$ Emphasis added here and in all subsequent examples.

** The paper is intended to illustrate the functions of word formation specific to the Ukrainian language. Henceforth the translations preserve the content of the original, but not its morphological, semantic or syntactic properties
} 
constitute from 45 to 70 percent of notional words, their function of semantic compression in the course of text production is highly significant.

Additionally, syntactic derivatives as a special type of derivative words expand the text-building functions of attributive words (adjectives and verbs) by providing the latter with broader syntactic and text-building possibilities. Due to their grammatical nature, attributive words are not involved in the subject-object relation. Created on the basis of attributive words, such derivatives acquire the referential meanings of quality, action or state, which allows for the possibility of using them as subjects or objects.

In the course of text production, a derivative is normally used together with its base. The use of a base-derivative pair in text generation is based primarily on repeating the base in the structure of the derivative. Analyzing the characteristics and categories of a fictional text, V. O. Lukin noted: "The notion of repetition is so essential because it determines coherence: a sequence of signs is regarded as coherent due to the repetition of various signs, their forms, as well as senses; while recurring, they bind, "sew together", such a sequence into one single whole" [8, p. 24]. Thus in text production, the primary function of a base-derivative pair lies in maintaining local coherence, cohesion, cf.: Я заперечував будьяку вищість російського, а для цьвого мусив їх шокувати. Моїм шокером була зневага, а моя зневага формою визволення (Yu. Andrukhovych. Leksykon intymnykh mist) (I rejected any superiority of whatever is Russian, and for that, I had to shock them. My shocker was contempt, and my contempt was a kind of liberation) (Yu. Andrukhovych. The Lexicon of Intimate Cities); Вдома дядько Микола виймае з кишені окуляри, чіпляе їх на самий кінчик носа, але читає, не заглядаючи в скельия <... Мати краєчком хустки витирае очі і питаеться читальника, чи він постує (M. Stelmakh. Husy-lebedi letiat...) (At home Uncle Mykola takes the glasses out of his pocket, puts them onto the tip of his nose and reads without looking through the lenses <...> Mother is wiping her eyes with the edge of her kerchief and asks the reader if he is fasting) (M. Stelmakh. The Magic Swan Geese Are Flying); Kазали, щьо брешу. А я рвався $i$ nаdав у болото iз знесилля і не уступав. Сказали, що я брехун іще раз. I покинули мене (V. Stefanyk. Moie slovo) (They said I was lying. And I was getting torn apart and falling into mud out of exhaustion and didn't surrender. They said again I was a liar. And they abandoned me) (V. Stefanyk. My Word); Tак, постать мандрівного дяка випадкового супутника і провожатого Марусі в подорожі справді позначена загадковістю: він навіть не має імені. Але безіменність засвідче не винятковість подібної постаті, а їі, сказати б, збірний xapaкmep (M. Ilnytskyi. Z choho postaie nepovtornist (Shtrykhy do portreta Liny Kostenko)) (Thus the character of the itinerant deacon - Marusia's accidental fellow traveler and guide is indeed marked by magic: he even has no name. But namelessness testifies not to the exceptionality of such a figure, but to their, let's say, composite character) (M. Ilnytskyi. What Inimitability Arises From (A Character Sketch of Lina Kostenko)); Венеція туманна. Ї̈ туманність у рази насиченіша від лондонської чи будь-якої іншої (Yu. Andrukhovych. Leksykon intymnykh mist) (Venice is foggy. Its fog is times as intense as that in London or elsewhere) (Yu. Andrukhovych. The Lexicon of Intimate Cities). In the excerpts given above, the derivatives occupy different semantic and syntactic positions in relation to their bases, but in all the cases it is a base-derivative pair that maintains the coherence of text components, that is, it serves as a two-component connector which links separate parts of the text. In every example given above, the derivative is an anaphoric element in the sense that it refers back to what was previously mentioned.

Cross-referential connection is similar to, but not identical with, anaphoric connection. The notion of cross-reference as a hyper-syntactic, textual, characteristic was introduced by V. Palek: "When mentioning one and the same object, we use the term 'object identification' and suggest that the means of expressing it in language be referred to as 'cross-reference'" [10, p. 246]. Cross-reference is normally associated with pronouns, articles, pronominal words, and particles. However, word-forming units can also be used for cross-reference, which manifests itself in structuring a text in such a way that its coherence is based on the use of the univerbated word and its base phrase, for instance: Тільки дочка середульша біля матері впада: - Мамонько! - Не перебивай! - Випийте, люба... - Що цзе? Валер'янові краплі. - Геть, одчепися! Хіба можна таку драму в серизі та валер'янкою впинити... Дай мені отрути! (M. Kulish. Narodnyi malakhii) (Only the middle daughter is attending to her mother: - Dear Mommy! - Don't interrupt! - Drink, dear ... - What's that? - Valerian drops. - Get away, leave me alone! Do you think one can possibly stop such a drama in one's heart with valerian ... Give me poison!) (M. Kulish. 
People's Malakhii). The derivative валер'янка, which is another way of referring to the identical object валер'янові краплі, is used for cross-reference purposes due to its ability to refer back to the source of motivation.

Syntactic derivatives can perform the same function since they inherit the lexical meaning of their bases without changing it, but they express it by means of another part of speech: Допит починався 3 того, щзо їх [безпартійну інтелігенціюе] трохи лякали, потім промовляли до їхнього радянського патріотизму. Але це лякання було тільки прелюдією до дальшого, і самі слідчі не надавали йому великої ваги (Yu. Shevelov. Ya - mene - meni... (i dovkruhy)) (At the beginning of the interrogation, they [non-party intelligentsia] were slightly intimidated; this was followed by an appeal to their Soviet patriotism. But this intimidation was only a prelude to something further, and the prosecutors themselves did not attach much weight to it) (Yu. Shevelov. I - Me - to Me... (and Around)). In the above-given excerpt, the verb ıskamu and the derivative word лякання have the same referent. Therefore, the syntactic derivative together with its base can also serve as a means of cross-reference in a text.

Text progression is a formal structural category, which generates text, builds up its content and changes (usually increases) the number of its formal structural elements [1, p. 187-188]. Text progression is directly connected with its thematic and rhematic constituents and, due to the motivation of the derivative word, allows for the possibility of correlating the rhematic constituent of the previous utterance with the thematic constituent of one of the last utterances [6, p. 186] thus unfolding the text. This property of a derivative word to create a functional perspective of the text, which manifests itself in thematizing the rheme of the previous utterance with the help of a syntactic derivative, is referred to as communicative progression [11, p. 61].

Complex word-forming units such as word-forming types, word-forming categories, word-forming paradigms, or word-forming sets cannot be involved in text production when they are regarded as units of classification and systematization. Their paradigmatic nature contradicts this in contrast to that of a text, whose components are syntagmatically related. However, the constituents of complex wordforming units can be used in text production, and they can realize certain textual categories.

The text-building functions of word-forming elements such as affix classes of various sizes (in instances of word-forming types or word-forming categories) or stem classes (in instances of wordforming paradigms or word-forming sets) are based on repeating an affix or a root morpheme in derivative structures used in the same text, and that can ensure the text's local connectedness (cohesion) and global connectedness (coherence), which has already been discussed [4, p. 46-50].

Another function of word-forming elements is connected with creating connotative components of textual semantics. The semantic structure of a text is composed of both denotative and connotative components. Word formation can perform significant text-building functions connected with generating textual connotations. This is most commonly achieved through the use of word-forming elements which carry evaluative, expressive connotations. These are primarily derivatives containing suffixes associated with subjective evaluation. Thus in the text given below, there is a prominent connotation, which features tender, affectionate feelings about the scenes depicted and overlaps with the denotative meaning; the connotation arises due in no small part to the use of diminutive derivatives such as сонечко, темнесенький, тихесенький: Тихесенький вечір на землю спадає, / I сонце сідає в темнесенький гай. / Ой сонечко ясне, невже ти втомилось? / Чи ти розгнівилось? Іщзе не лягай. (V. Samiilenko. Vechirnia pisnia) (Sweet quiet evening is falling onto the earth, / And the sun is setting into a lovely little dark wood. / Oh, little bright son, how can you possibly be tired? / Or are you furious? Don't go to sleep yet.) (V. Samiilenko. An Evening Song).

Texts can gain expressivity due to the use of nonce-words, whose connotations result from intentional violation of word formation rules. Thus in the Ukrainian language, the suffix $-\mathcal{H} u \mathcal{K}$ is commonly used to form derivatives from nouns and adjectives. However, once this suffix is added to an adverb, the derivative acquires strong expressive power, which irradiates onto the whole text chunk, cf.: Іванка вже здогадується, напевне, щось, така сумна і самотня, мені іноді стає ї жаль, скільки перетерпіти разом, але вона має, на відміну від більшості хитрозроблених галичанок, добру закваску. Але мені мало усвідомлення дружини як соратника чи пліч-о-плічника. Щось таке важливе $i$ 
сокровенне ми витратили за переӥздами, вічними побутовими клопотами (S. Protsiuk. Infektsiia) (Ivanka is probably suspecting something already; she looks so sad and lonely; I sometimes feel so sorry for her; we have been through so much together; but unlike most crafty Galician ladies, she's got the right stuff. But I cannot content myself with perceiving my wife only as an ally or a shoulder-to-shoulder person. Being too busy moving house and coping with domestic hassle, we have lost something so very important and intimate) (S. Protsiuk. Infection).

Texts can acquire connotations due to the use of pragmatically saturated word-forming elements. This can be achieved by semantically close or contrasting derivational elements; semantically equivalent derivatives formed from the same root word (for instance, if the meaning of one of them is neutral or positive and the other one carries negative connotations); paronyms; a stylistic play on derivational triggers, etc. To illustrate, let us consider P. Osadchuk's epigram: Жили в Україні, як дачники, / Українську зневаживщи суть, / Нині ж там у державі Табачники, / Де б Тютюнники мали бymo (In Ukraine, they used to live like "dachnyky" / Despising Ukrainian identity, I And now they have Tabachnyks in the country, I Instead of Tiutiunnyks who were supposed to be there).

In this epigram, the connotations arise from a specific use of word-forming elements - juxtaposing two homogeneous derived last names of statesmen who embody diametrically opposite visions of building the country. The connotation is enhanced and extended due to the fact that one last name is derived from Ukrainian and the other from Russian.

Texts can acquire connotations when different meanings of a polysemous source word are activated in one text chunk thus creating homonymous derivatives, cf.: Дорогий Дмитре Васильовичу! Я все-таки наполягаю на тому, що ви найкращий перекладач. Ви успішно переклали відповідальність за долю України з СРСР на власні плечі (Iz pryvitannia zastupnyka holovy Ivano-Frankivskoi oblderzhadministratsii B. Tomenchuka na yuvileinomu vechori do 70-richchia D. Pavlychka v Prykarpatskomu universyteti im. Vasylia Stefanyka 1999r.) (Dear Dmytro Vasylovych! I do insist that you are the best translator. You have successfully translated the USSR's responsibility for Ukraine's destiny into your own responsibility) (An extract from the speech of B. Tomenchuk, deputy head of Ivano-Frankivsk Region Council, given at the jubilee celebration dedicated to the 70th anniversary of D. Pavlychko held at Vasyl Stefanyk Precarpathian University in 1999). If the addresser uses words formed from the same root as the text unfolds, the addressee expects a semantically related lexeme. It is known that D. Pavlychko is a brilliant translator from various languages into Ukrainian. Thus in the above-given excerpt, though the Ukrainian verb perekladaty (i.e. to translate - transl. note) is homophonous with the derived form perekladach (i.e. translator - transl. note), the two words are perceived as semantically contradictory: the verb perekladaty does not refer to changing words into another language, but to shifting responsibility onto someone. The connotation arises from the interplay between the pseudo-motivating meaning of the source word and its derivative formed from another meaning of this source word.

Expressivity can result from the juxtaposition of homonymous words, cf.: Дощ, полив, і день такий полив'яний, / Все блищцть, і люди як нові. / Аищ дідок старесенький, кропив'яний, / блискавки визбируе в mpaвi (L. Kostenko. Doshch polyv) (Down came the rain, watering all around; and the day is so well watered; I Everything is glistening; and the people are as good as new. I A little old man carrying nettle leaves is picking up tiny glistening lights from the grass) (L. Kostenko. Down Came the Rain, Watering All Around).

The meaning of the attributive adjective полив'яний is motivated by the noun polyvo (i.e. weed transl. note) and is thus unrelated to the verb полив (i.e. watered - transl. note). However, since the two words sound similar and share a common etymon, it is possible to juxtapose them in a text in order to make it more expressive.

Connotations can arise from the use of base-derivative pairs, cf.: Мати сіяла сніг, / Щоб він м'яко до ніг, / А вродило зілля. / I хоч січень січе, / А мені за плечем / Журавлі журавлять! (B. Oliinyk. Maty siiala son) (Mother was sowing snow, / So that it would lie soft for the feet to touch, / But vegetation was brought forth instead. I And though January snow is slashing down, / From over my shoulder / I can hear storks

\footnotetext{
* Transl. note: the word dachnyky refers to residents of dachas, i.e. country houses in the former USSR; dachas were used as temporary, second homes - their owners worked in towns and came only for their vacations and/or, when they did not live too far, on weekends.
} 
clattering!) (B. Oliinyk. Mother Was Sowing Sleep). The base-derivative pairs січе - січень and журавлiжуравлять not only display predicative relations, but also enhance the lyricism, musicality, and expressiveness of the text.

Paronymy, which is based on word formation, can also be effective in creating connotations: Україні потрібен націоналізм дї, націоналізм економічного поступу, націоналізм самоутвердження серед світових народів, бо тільки він зможе поняття Західної і Східної Украйни з розряду політичних перевести в розряд географічних. За інших підходів наш патріотизм залишиться вишиванковим галичанством, що рано чи пізно стане сприйматися як опереткове галичванство (B. Tomenchuk. Iz vystupu na urochystomu zasidanni, prysviachenomu Dniu sobornosti Ukrainy, 2002 rik) (Ukraine needs the nationalism of action, the nationalism of economic growth, the nationalism of self-identification among peoples of the world because only this will be able to transfer the notions of Western and Eastern Ukraine from the political to the geographical domain. Under other approaches, our patriotism will be reduced to vyshyvanka-clad* Galicians, which will sooner or later come to be perceived as stagy Galician ethnocentrism) (B. Tomenchuk. An extract from the speech at the ceremonial celebrating the Day of Ukraine's Sobornist in 2002).

Similar processes can be traced in the following excerpt: Але була одна частина радянського загального мовознавства, що претендувала на свою марксистськість, - так звана "нова наука про мову", простомовно марризм. Щодо неї Булаховський не хотів і не міг приховувати свого різкого заперечення. Йому приписувано гру слів: - Це не марризм, це маразм! (Yu. Shevelov. Ya - mene - meni... (i dovkruhy)) (But there was one part of Soviet general linguistics that claimed to be Marxist, the so-called "new science about language", which is referred to as marrism in layman's terms. Bulakhovskyi did not want and could not hide his harsh rejection of it. He is credited with the following play on words: - It is not marrism; it is marasmus!) (Yu. Shevelov. I-Me - to Me... (and Around)).

In the excerpts given above, the idea becomes more prominent due to the paronomastic relations between the derivatives which carry expressive negative connotations; this adds a subjective note to the text's denotative meaning.

\section{CONCLUSIONS}

Therefore, various types of word-forming elements play different roles in the semantic organization of a text. Basic word-forming elements maintain the local coherence of a text and serve as linking devices for expressing a single meaning, which enhances textual unity. Being units of nomination, derivational elements serve as structural and semantic material for creating textual categories; and due to their nature, they allow for an unambiguous and economical representation of information thus eliminating grammatical cumbersomeness and syntactic overload. The base-derivative pair can link separate parts of a text thus maintaining its progression. The components of complex units can be used for coherence and cohesion. In text generation, word-forming elements also perform the important function of generating textual connotations.

\section{REFERENCES}

[1] Бацевич Ф., Кочан І. Лінгвістика тексту. ЛНУ ім. Івана Франка, Львів, 2016. [Batsevych F., Kochan I. Linhvistyka tekstu. LNU im. Ivana Franka, Lviv, 2016.]

[2] Вихованець I. Частини мови в семантико-граматичному аспекті. Наук. думка, Київ, 1988. [Vykhovanets I. Chastyny movy v semantyko-hramatychnomu aspekti. Nauk. dumka, Kyiv, 1988.]

\footnotetext{
${ }^{*}$ Transl. note: vyshyvanka is a Ukrainian embroidered shirt, part of the Ukrainian national costume.
} 
[3] Грещук В.В. Виокремлення і лексикалізація словотворчих формантів як текстотворчий засіб. В: Історія та сучасний стан функціонування граматичної системи української мови: на пошанування акад. А. П. Грищенка з нагоди його 70-річчя. Брама-Україна, Черкаси, 2006, 33-41.

[Greshchuk V.V. Vyokremlennia i leksykalizatsiia slovotvorchykh formantiv yak tekstotvorchyi zasib. In: Istoriia ta suchasnyi stan funktsionuvannia hramatychnoi systemy ukrainskoi movy: na poshanuvannia akad. A. P. Hryshchenka z nahody yoho 70-richchia. Brama-Ukraina, Cherkasy, 2006, 33-41.]

[4] Грещук В.В. Словотвір у текстотворенні. Вісник Аьвівського університету. Серія філологічна, 70 (2019), 43-51.

[Greshchuk V.V. Slovotvir u tekstotvorenni. Visnyk Lvivskoho universytetu. Seriia filolohichna, 70 (2019), 43-51.]

[5] Земская Е. Словообразование и текст. Вопросы языкознания, 6 (1990), 17-30.

[Zemskaya E. Slovoobrazovaniye i tekst. Voprosy yazykoznaniya, 6 (1990), 17-30.]

[6] Кубрякова Е. Типь языковых значений: Семантика производного слова. Москва, 1981.

[Kubryakova E. Tipy yazykovykh znachenii: Semantika proizvodnogo slova. Moskva, 1981.]

[7] Курилович Е. Деривация лексическая и деривация синтаксическая. В: Курилович Е. Очерки по лингвистике. Изд-во иностранной дитературы, Москва, 1962, 57-70.

[Kurilovich E. Derivatsiya leksicheskaya i derivatsiya sintaksicheskaya. In: Kurilovich E. Ocherki po lingvistike. Izd-vo inostrannoi literatury, Moskva, 1962, 57-70.]

[8] Аукин В.А. Художественный текст: Основы хингвистической теории. Аналитический минимум. 2-е изд., перераб. и доп. Ось-89, Москва, 2005.

[Lukin V.A. Khudozhestvennyi tekst: Osnovy lingvisticheskoi teorii. Analiticheskii minimum. 2-e izd., pererab. i dop. Os-89, Moskva, 2005.]

[9] Николаева Т.М. Аингвистика текста. Современное состояние и перспективы. Новое в зарубежной лингвистике. Аингвистика текста, 8 (1978), 5-39.

[Nikolaeva T.M. Lingvistika teksta. Sovremennoe sostoyanie i perspektivy. Novoe $v$ zarubezhnoi lingvistike. Lingvistika teksta, 8 (1978), 5-39.]

[10] Палек В. Кросс-референция: к вопросу о гиперсинтаксисе. Новое в зарубежной лингвистике. Пингвистика текста, 8 (1978), 243-258.

[Palek V. Kross-referentsiya: k voprosu o gipersintaksise. Novoe v zarubezhnoi lingvistike. Lingvistika teksta, 8 (1978), 243-258.]

[11] Шадрин В.И. О текстообразующих функциях производных слов в английском языке. В: Вопросы анализа специильного текста. Уфа, 1987, 60-65.

[Shadrin V.I. O tekstoobrazuyushchikh funktsiyakh proizvodnykh slov $\mathrm{v}$ angliiskom yazyke. In: Voprosy analiza spetsialnogo teksta. Ufa, 1987, 60-65.]

Address: Vasyl Greshchuk, Vasyl Stefanyk Precarpathian National University, 57 Shevchenko St., IvanoFrankivsk, 76025 Ukraine.

E-mail: ukrinst.pu.if@gmail.com

Received: April 28, 2020; revised: October 15, 2020.

Грещук Василь. Текстотвірні функції словотвірних одиниць. Журнал Прикарпатського університету імені Василя Стефаника, 7 (2) (2020), 61-68.

У статті аналізуються мождивості словотвірних одиниць у процесі породження тексту. Різні дериваційні величини - елементарні словотвірні одиниці, похідні слова, словотвірні пари, комплексні словотвірні одиниці - неоднаково залучені до текстотворення. Словотвірні форманти можуть виконувати текстоорієновані функції лише в структурі дериватів. Певним чином розташовані у висловлюванні, зокрема деривати одного словотвірного типу, похідні 3 анатомічними або 
паронімічними афіксами тощо можуть реалізувати локальну зв'язність тексту. У випадках виокремлення й лексикалізації дериваційного форманта виділяємо функцію специфічної номінації в тексті з досить високим ступенем узагальнення, яка не має в мові однослівного найменування. Похідні слова разом із непохідними формують лексико-семантичний текстовий рівень, тобто виконують конститутивну текстотвірну функцію. Деривати у процесі породження тексту виконують функцію економного раціонального подання інформації, яке дає змогу уникати граматичної громіздкості та синтаксичного ускладнення, тобто функцію семантичної компресії. Синтаксичні деривати, крім того, забезпечуючи ширші синтаксичні й текстотвірні можливості класу ознакових слів (прикметників та дієслів), виконують номіналізаційну функцію. Словотвірна пара “твірне-похідне” у текстотворенні використовується як двокомпонентний конектор, що поєднує дві окремі частини тексту між собою і реалізуе його локальну зв'язність. Крім того, синтаксичні деривати разом із своїми твірними словами нерідко забезпечують текстотвірну функцію комунікативної прогресії. Текстотвірне використання комплексних словотвірних одиниць, які репрезентовано більшими чи меншими афіксальними спільнотами (якщо йдеться про словотвірний тип чи словотвірну категорію) або кореневими спільнотами (якщо йдеться про словотвірну парадигму чи словотвірне гніздо) грунтується на повторенні в структурах дериватів в одному тексті афікса або кореневої морфеми, що може забезпечити як когезію, так і когерентність тексту. Нарешті словотвірні одиниці виконують функцію творення конотативного компонента семантики тексту.

Ключові слова: когезія, когерентність, конотація тексту, прогресія тексту, словотвір, словотвірні одиниці, текстотворення. 